\title{
ANALISIS LAYANAN AKADEMIK BERBASIS DIGITAL SIGNAGE
}

\author{
Novita Kamaruddin \\ Universitas Padjadjaran \\ Jalan Raya Bandung Sumedang km 21, Jatinangor Kabupaten Bandung \\ e-mail : Nvita@unpad.ac.id
}

\begin{abstract}
ABSTRAK
Perkembangan teknologi saat ini sehingga perlu juga dalam layanan akademik pada perguruan tinggi yang berbasis teknologi. Tujuan penelitian ini untuk mengetahui bagaimana media layanan akademik berbasik teknologi. Metode penelitian menggunakan metode survey dengan pendekatan deskriptif kuantitatif. Analisis data dengan menggunakan SPSS. Responden pada penelitian ini sebanyak 64 responden dengan teknik pengambilan sampel volunteer sampling. Hasil Penelitian menunjukkan bahwa responden sangat antusias jika layanan akademik akan berubah menjadi layanan akademik berbasis teknologi infomasi. Hampir seluruh responden yaitu sebesar 98,4 persen yang menyukai informasi secara digital. Layanan akdemik berbasis digital merupakan inovasi melalui teknologi digital signage yang dapat menginformasikan layanan akademik secara realtime, dapat meningkatkan motivasi bagi mahasiswa terhadap kelulusan tepat waktu dan meningkatkan kualitas dengan berprestasi.
\end{abstract}

Kata kunci : Akademik, digital signage, layanan

\section{ABSTRACT}

Current technological developments so that it is also necessary for academic services at technology-based tertiary institutions. The purpose of this study was to determine how technology-based academic service media. The research method used a survey method with a quantitative descriptive approach. Data analysis using SPSS. Respondents in this study were 64 respondents using a volunteer sampling technique. The results showed that the respondents were very enthusiastic if academic services would change to information technology-based academic services. Almost all respondents, 98.4 per cent, like digital information. Milea is innovation through digital signage technology that can inform academic services in real-time, can increase motivation for students to graduate on time and improve quality by achieving.

Keywords: Academic, digital signage, service

\section{PENDAHULUAN}

Suatu organisasi/institusi selalu berhubungan dengan informasi. Informasi merupakan segala sesuatu yang berisikan data yang sudah diolah dan memiliki arti (Jumardi \& Farokhah, 2020). Informasi yang disampaikan harus jelas, akurat dan update sehingga dapat dengan mudah memahami informasi tersebut. Perkembangan teknologi pada revolusi industri 4.0, sehingga pemberian informasi harus disesuaikan dengan teknologi yang berkembang. Perkembangan teknologi yang semakin cepat dan meluas, sehingga perlu menyesuaikan dengan perkembangan teknologi saat ini. Penyediaan informasi melalui teknologi digital disebut dengan digital signage.

Digital signage merupakan bentuk elektronik yang menunjukkan informasi dan juga dapat dijadikan sebagai platform komunikasi. Digital Signage merupakan teknologi penyebaran informasi yang telah diprogram dengan memberikan konten digital agar dapat menampilkan rangkaian informasi atau pesan kepada audiens secara efektif, cepat, dan tepat serta akurat. Digital Signage menggunakan jaringan dan menggunakan aplikasi yang smart (Lee \& Yoon, 2014). Digital Signage memiliki 
IN F ORMA TIK

Jurnal Informatika, Manajemen dan Komputer, Vol. 12 No. 2, Desember 2020

eISSN : 2580-3042

pISSN : 1979-0694

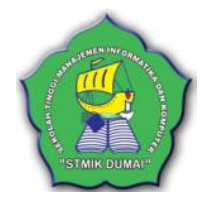

kelebihan dibandingkan media konvensional karena dapat memanjakan mata anda dalam memberikan tontonan visual yang menarik dan atraktif, beraneka pesan atau informasi berformat multimedia, antara lain berupa gambar, video, scroll text, chart, grafik, schedule, news, weather yang disajikan secara dinamik menggunakan media display elektronik seperti LCD TV, PLASMA TV, Proyektor, digital billboard sebagai output. TV Plasma digunakan untuk menampilkan display hasil desain konten papan pengumuman digital yang telah dibuat agar terlihat lebih tajam, cerah, dan besar jika dibandingkan menggunakan monitor komputer biasa (Ariawan, 2016). Digital Signage dengan menggunakan teknologi LCD, LED ataupun plasma yang semakin canggih dan mudah digunakan, sehingga menjadi trend dan sudah banyak digunakan.

Digital signage merupakan layar elektronik dengan metode tertentu dan sudah banyak dipasang pada area-area publik (Ariawan, 2016). Saat ini digital signage sudah menjadi trend dan banyak digunakan bagi perkantoran/perusahaan, shooping mall, bandara dan tempat fasilitas umum lainnya (Suryanata \& Wardana, 2014). Digital signage pada perguruan tinggi dapat diterapkan sebagai media informasi digital menggantikan papan pengumuman tradisional ataupun menginformasikan informasi secara update. Tampilan dari informasi yang disampaikan sangat memengaruhi kualitas informasi, khususnya mahasiswa di suatu kampus (Mulyana \& Aria, 2015). Digital signage bersifat dinamis, kontennya dapat diperbaharui secara update tanpa perlu mengeluarkan biaya percetakan (Suranata \& Wardana, 2014). Akademik Fakultas Keperawatan Universitas Padjadjaran ingin mencoba menerapkan informasi akademik dengan digital signage. Saat ini jika ada pengumuman dari akademik maka disampaikan ke mahasiswa bagian adkesma BEM. Adkesma merupakan singkatan dari Advokasi dan kesejahteraan mahasiswa, ini merupakan departemen dari BEM Fkep. Anggota adkesma akan memberikan informasi melalui instagram BEM, terkadang memberikan informasi langsung ke ketua angkatan melalui whatsapp. Bagian akademik juga harus menginformasikan ke tim dosen di bagian yang menerima informasi akademik, sehingga memberi informasi kepada mahasiswa dan dosen. Hal ini sangat tidak efektif karena harus memberikan informasi kepada mahasiswa untuk disebarkan ke rekan mahasiswa lain dan kepada

dosen untuk di share ke dosen lainnya. Pemberian informasi melalui instagram juga belum efektif karena tidak semua mahasiswa selalu mengecek instagram. Selain itu ada beberapa kali terjadi perubahan jadwal perkuliahan dan ruangan secara mendadak. Seperti diketahui bahwa semua gedung merupakan fasilitas Universitas Padjadjaran, sehingga ruangan fakultas juga sering digunakan untuk kegiatan pusat, contoh aula. Efektifitas digital signage sangat dipengaruhi oleh strategi penyampaian pesan layanan ini diletakkan di tempat yang strategis (Panuntun, Rochim, \& Martono, 2015).

Pengumuman yang diformasikan melalui papan informasi digital merupakan upaya untuk memberikan layanan akademik melalui database layanan akademik digital. Akademik menyediakan informasi dari basis data informasi akademik diharapkan menjadi solusi bagi mahasiswa sebagai upaya peningkatan daya saing dalam mengendalikan informasi (Cahyana, 2014). Banyak kelebihan dari penyampaian informasi melalui digital signage antara lain, menghemat biaya cetak dan produksi, tampilan yang eye catching atau atraktif akan mampu menarik perhatian orang banyak, dan dapat cepat mengupdate konten visual serta dapat diubah secara realtime.

\section{METODOLOGI PENELITIAN}

Metode penelitian yang digunakan pada penelitian ini bersifat kuantitatif. Berdasarkan permasalahan yang dibahas pada penelitian, maka peneliti mencoba untuk melihat antusias mahasiswa terhadap penerapan layanan akademik berbasis digital signage.

a. Metode Pengumpulan Data

Dalam pengumpulan data dilakukan sebagai berikut:

1. Observasi

Penelitian ini dilakukan dengan menggunakan metode survei yakni dengan cara menyebarkan kuesioner terhadap mahasiswa pada fakultas Keperawatan Universitas Padjadjaran. Jumlah responden sebanyak 64 orang. Teknik sampling yang digunakan adalah volunteer sampling. Analisis data dengan distribusi frekuensi dengan menggunakan software SPSS.

2. Studi Literatur

Metode yang dilakukan berdasarkan jurnal dan buku. Selain itu informasi yang diperoleh 
IN F ORMA TIK

Jurnal Informatika, Manajemen dan Komputer, Vol. 12 No. 2, Desember 2020

eISSN : 2580-3042

pISSN : 1979-0694

melalui internet yang berhubungan dengan tema, topik dan permasalahan dalam penelitian.

\section{Analisis Sistem}

Tahap ini penulis mulai mengidentifikasi permasalahan yang ada dalam layanan akademik. Layanan akademik yang diberikan, jika ada perubahan jadwal mata kuliah masih menggunakan person by person. Akademik akan memberikan informasi perubahan jadwal ke tim perwakilan dosen dan perwakilan mahasiswa bagian adkesma dari BEM. Begitupun informasi layanan seperti jadwal sidang. Meskipun saat ini mahasiswa dapat melihat informasi jadwal sidang pada Sistem Informasi Akademik Terpadu (SIAT) yang berbasis web, namun dengan digital signage semua dapat melihat layanan akademik dengan TV display. Berdasarkan analisis penulis maka perlu adanya pengembangan sistem dalam layanan akademik berbasis teknologi display yaitu digital signage. Pembuatan sistem pada layanan akademik yang berbasis web menjadi tampilan berbasis digital untuk beberapa bentuk layanan akademik.

4. Metode Pengembangan Perangkat Lunak Pengembangan perangkat lunak menggunakan software Java Script Reactnative dengan menggunakan Mongo database. Pemrosesan data bisa dilakukan lebih cepat dengan menggunakan metode ini. Hal ini terjadi karena data di buffer di memori.

\section{Perancangan Sistem}

\section{Architecture system}

Architecture system merupakan rangkaian proses mulai awal hingga tampil pada display, terlampir pada Gambar 1.

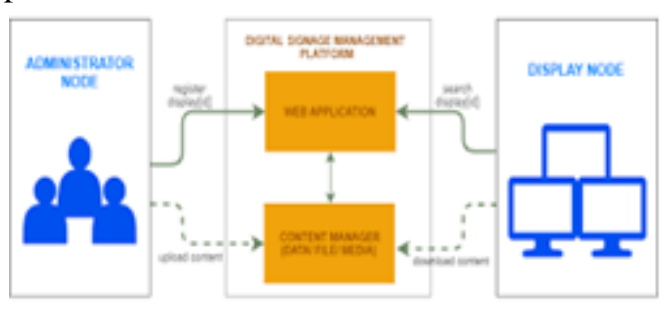

Gambar 1. Architecture System

Ada 4 tahapan dalam architecture sebagai berikut:

1 Local Admin dapat merubah format ataupun isi informasi menggunakan local web based (http).

2 Informasi berupa slideshow gambar, stream video, text dan animasi.

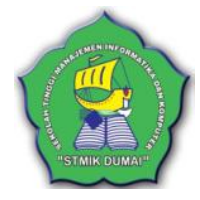

3 Menggunakan tambahan device raspberry pi di setiap LCD TV.

4 Menggunakan koneksi internet untuk content video.

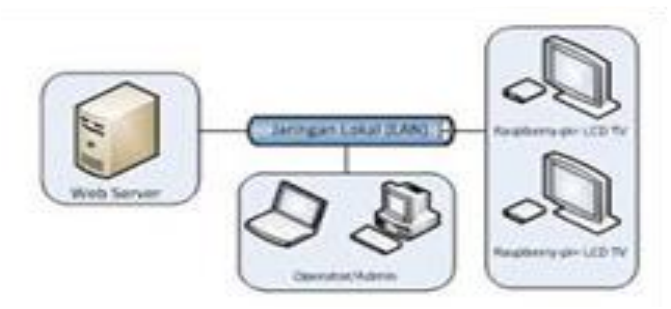

Gambar 2. Perangkat Tambahan pada LCD

Gambar 2 menunjukkan alur sistem perangkat yang dibutuhkan untuk menghubungan proses pada tampilan digital signage pada LCD TV (Panuntun et al., 2015)

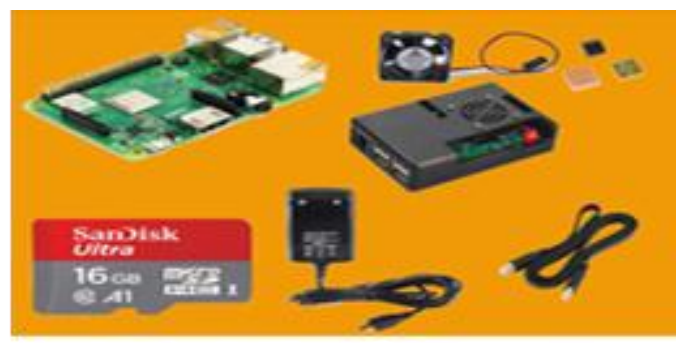

Gambar 3. Prototype Complete Display Raspberry pi pada LCD TV

\section{HASIL DAN PEMBAHASAN}

\section{Karakteristik responden}

Karakterisitik responden terlampir pada Tabel 1. Tabel 1. Karakteristik Responden

\begin{tabular}{|c|c|c|c|}
\hline \multirow[b]{2}{*}{$\begin{array}{l}\text { Karakteristik } \\
\text { Responden }\end{array}$} & \multirow[b]{2}{*}{ Kategori } & \multicolumn{2}{|c|}{ Mahasiswa } \\
\hline & & $\begin{array}{l}\text { Jumlah } \\
\text { (n) }\end{array}$ & $\begin{array}{c}\text { Perse } \\
\text { ntase } \\
\text { (n) }\end{array}$ \\
\hline \multirow[t]{3}{*}{ Jenis Kelamin } & Laki-Laki & 5 & 7,9 \\
\hline & Perempuan & 58 & 92,1 \\
\hline & Total & 63 & 100 \\
\hline
\end{tabular}

Berdasarkan Tabel 1 bahwa responden penelitian ini menunjukkan laki-laki sebesar 7,9 persen dan perempuan sebesar 92,1 persen. Hal tersebut menunjukkan dominan mahasiswa perempuan pada Fakultas Keperawatan Unpad disebabkan banyak mahasiswa perempuan yang tertarik dengan keperawatan dibandingkan lakilaki. 
IN F O R M A I I A

Jurnal Informatika, Manajemen dan Komputer, Vol. 12 No. 2, Desember 2020

eISSN : 2580-3042

pISSN : 1979-0694

Permasalahan Akademik yang terjadi menjadikan pertanyaan yang kami ajukan untuk mencari informasi di lapangan.

Tabel 2. Kendala yang dialami

\begin{tabular}{|c|c|c|c|}
\hline \multirow[b]{2}{*}{ NO } & \multirow[b]{2}{*}{ Pertanyaan } & \multicolumn{2}{|c|}{ Mahasiswa } \\
\hline & & Jumlah (n) & $\begin{array}{c}\text { Persentase } \\
\text { (n) }\end{array}$ \\
\hline \multirow[t]{2}{*}{1} & Mengalami & 10 (Tidak) & 15,9 \\
\hline & $\begin{array}{l}\text { perubahan } \\
\text { jadwal ruangan } \\
\text { mendadak }\end{array}$ & 53 (Pernah) & 84,1 \\
\hline \multirow[t]{2}{*}{2} & Mengalami & 7 (Tidak) & 11,1 \\
\hline & $\begin{array}{l}\text { dosen yang } \\
\text { mendadak } \\
\text { pemberitahuan } \\
\text { tidak masuk }\end{array}$ & 56 (Pernah) & 88,9 \\
\hline \multirow[t]{2}{*}{3} & Yang menyukai & 1 (Tidak) & 1,6 \\
\hline & informasi digital & 62 (Suka) & 98,4 \\
\hline \multirow[t]{2}{*}{4} & Setuju layanan & 19 (Tidak) & 30,2 \\
\hline & $\begin{array}{l}\text { akademik } \\
\text { dengan digital } \\
\text { signage }\end{array}$ & 43 (Setuju) & 68,3 \\
\hline \multirow[t]{2}{*}{5} & Informasi & 4 (Tidak) & 6,3 \\
\hline & $\begin{array}{l}\text { mahasiswa } \\
\text { berprestasi pada } \\
\text { layar display } \mathrm{TV}\end{array}$ & 59 (Setuju) & 93,7 \\
\hline \multirow[t]{3}{*}{6} & Yang mengenal & 57 (Tidak) & 90,5 \\
\hline & produk yang & 6 & 9,5 \\
\hline & $\begin{array}{l}\text { dihasilkan } \\
\text { unpad }\end{array}$ & (Mengetahui) & \\
\hline
\end{tabular}

Berdasarkan Tabel 2 menunjukkan bahwa sebagian besar mahasiswa pernah mengalami perubahan ruangan secara mendadak dan mengalami informasi mendadak atas ketidakhadiran dosen pada saat hari pelaksanaan pembelajaran. Perkembangan teknologi saat ini, sehingga dunia pendidikan juga sangat bagus dengan adanya inovasi digital signage. Hampir seluruh responden yaitu sebesar 98,4 persen yang menyukai informasi secara digital.

Berdasarkan hasil penelitian mahasiswa yang setuju layanan akademik dengan digital signage sebesar 68,3 persen. Informasi yang disampaikan di media display televsi terhadap mahasiswa berprestasi sangat mendapat persepsi yang tinggi dari responden sebesar 93,7 persen. Sebagai civitas akademika, terdapat 90,5 persen yang tidak mengenal produk-produk yang dihasilkan dan dikomersilkan oleh Universitas Padjadjaran, hanya 9,5 persen yang mengenal hasil produk Universitas Padjadjaran.

Mahasiswa sebagai konsumen perguruan tinggi memiliki peran dalam indikator penilaian reputasi/peringkat dengan kelulusan tepat waktu. Berdasarkan hasil penelitian bahwa

informasi jadwal yang ditampilkan melalui digital signage sangat memberi motivasi bagi mahasiswa lainnya dan ini akan berimpact pada kelulusan mahasiswa, terlampir pada Gambar 4.

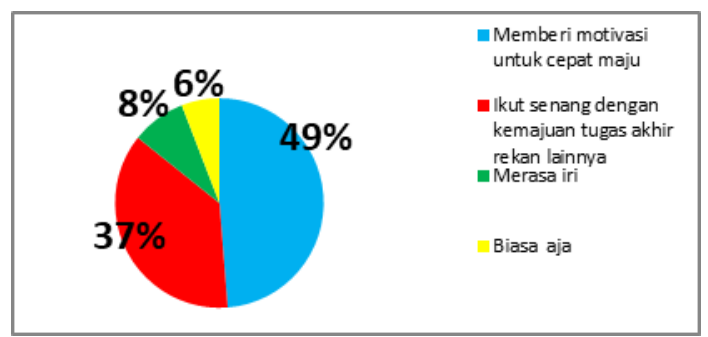

Gambar 4. Pengaruh jika jadwal ujian proposal/siding ditampilkan di layar TV

Selain itu mahasiswa memberikan pilihan dan pendapat informasi apa saja yang akan ditampilkan pada media display TV untuk memberikan informasi yang sangat bermanfaat dalam memberikan layanan akademik dan implementasi teknologi digital melalui digital signage terlampir pada Gambar 5.

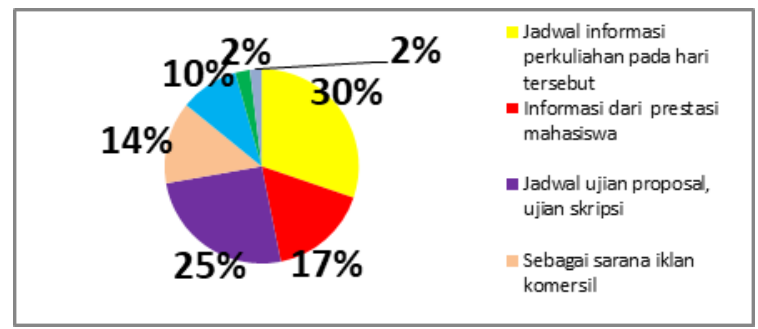

Gambar 5. Berbagai Informasi dalam Teknologi Digital Signage

Layanan akademik berbasis digital signage merupakan inovasi yang akan diterapkan sebagai media informasi layanan elektronik akademik (MILEA) yang dapat memberikan informasi secara update, cepat, efisien, akurat serta handal. Akademik dapat menginformasikan jadwal perkuliahan beserta ruangan dan nama dosen melalui media display televisi, sehingga akademik tidak perlu memberikan informasi secara personal ke dosen, mahasiswa untuk di share ke lainnya. Mahasiswa dan dosen langsung dapat melihat semua informasi akademik di layar TV. Jadwal perkuliahan, ruangan, pengumuman update dari akademik, semua dapat dilihat melalui layar TV digital. Milea juga dapat menginformasikan jadwal ujian proposal mahasiswa ataupun jadwal sidang Skripsi/Tesis 
IN F O R M A I I A

Jurnal Informatika, Manajemen dan Komputer, Vol. 12 No. 2, Desember 2020

eISSN : 2580-3042

pISSN : 1979-0694

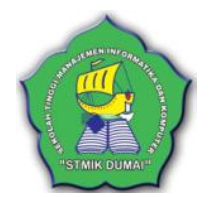

sehingga akan meningkatkan motivasi bagi rekan mahasiswa lainnya untuk juga terpacu agar cepat juga mendapatkan jadwal ujian proposal ataupun skripsi. Motivasi yang terbentuk akan memberi dampak dengan semakin banyak mahasiswa yang lulus tepat waktu. Capaian persentase kelulusan tepat waktu akan memberi impact kepada Unpad capaian indikator kelulusan mahasiswa tepat waktu.

Prestasi dari mahasiswa juga dapat diinformasikan melalui Milea sehingga ada kebanggaan di diri mahasiswa tersebut karena telah membawa harum nama fakultas atau institusinya dan memberikan motivasi kepada mahasiswa lainnya untuk juga ikut berprestasi dan meningkatkan kualitasnya. Berdasarkan hasil penelitian, hampir sebagian besar responden menyetujui mahasiswa berprestasi ditampilkan pada layar media display TV karena memberi motivasi bagi mahasiswa lainnya, inovasi akademik digital signage dapat mewujudkannya dengan teknologi digital.

Inovasi Milea ditampilkan pada media TV yang dipasang di dinding sehingga semua pihak dapat melihat dengan mudah semua informasi akademik yang uptodate. Desain visual inovasi Milea berisikan informasi update akademik seperti jadwal perkuliahan, jadwal ujian, sidang, bentuk visual terlampir pada Gambar 6.
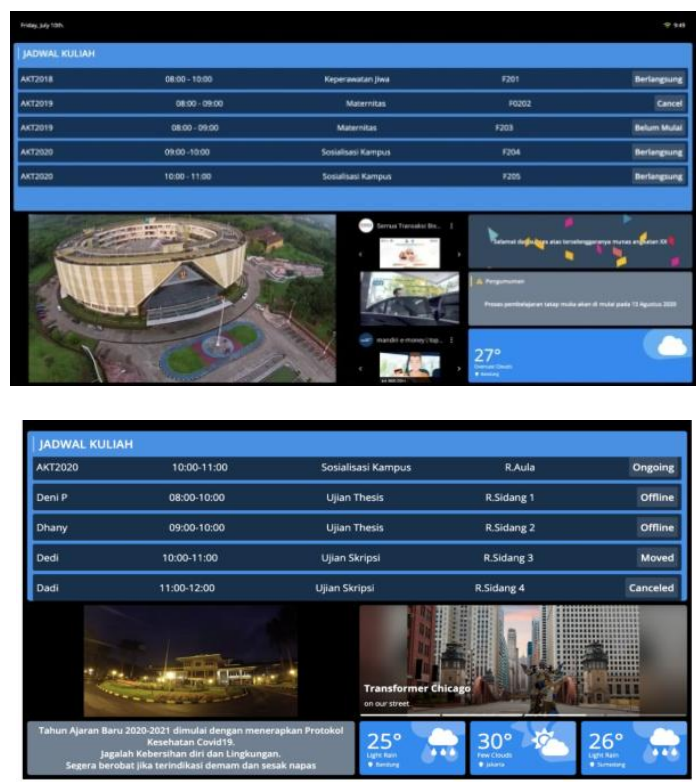

Gambar 6. Desain Visual Digital Signage Milea

Berdasarkan Gambar 6 bahwa implementasi digital signage melalui inovasi Milea akan menampilkan informasi jadwal perkuliahan,

ruangan yang digunakan dan informasi akademik lainnya. Informasi yang diperoleh dari mahasiswa bahwa kadang saat sudah berada di kelas mendapatkan informasi dosen tidak jadi masuk mengajar ataupun perubahan jadwal mengajar 1 jam sebelum dilaksanakan pembelajaran. Selain itu dosen juga dapat melihat ruangan jadwal mata kuliah hari tersebut sehingga tidak perlu lagi menanyakan ruangan di akademik.

Mahasiswa yang akan melakukan ujian proposal dan sidang skripsi/tesis pada hari tersebut akan ditampilkan pada media display TV sehingga akan memotivasi bagi rekan mahasiswa lainnya. Selain itu mahasiswa yang memiliki prestasi bisa ditampilkan berupa video wawancara atau foto-foto yang sudah dijadikan video sehingga menjadi kebanggaan bagi diri sendiri dan bagi institusi tentunya karena sudah membawa harum nama institusi. Hal ini juga dapat memberikan motivasi bagi mahasiswa lainnya untuk turut mengikuti lomba yang banyak ditawarkan dalam kegiatan lokal, regional, nasional maupun international.

\section{KESIMPULAN}

Milea merupakan inovasi melalui teknologi digital signage yang dapat menginformasikan layanan akademik secara realtime, dapat meningkatkan motivasi bagi mahasiswa terhadap kelulusan tepat waktu dan meningkatkan kualitas dengan berprestasi. Selain itu, Milea meningkatkan image fakultas atas inovasi teknologi digital yang digunakan, dan memberi impact terhadap Unpad atas indikator mahasiswa lulus tepat waktu.

\section{REFERENSI}

Ariawan, K. U. (2016). Unjuk Kerja Aplikasi Digital Signage Xibo Pada Proses Pembuatan Papan Pengumuman Digital Di Jurusan Teknik Elektro. Digital Information \& Systems Conference, 13(1), 50-60.

Cahyana, R. (2014). The Service Candidate Modelling of Academic Information Channel by Appliying of Service OrientedArchitecture. International Journal of Basic and Applied Science, 1(2), 82-87.

Jumardi, R., \& Farokhah, L. (2020). Kolaborasi Digital Signage dan Chatbot Messenger Sebagai Layanan Penyedia Informasi Akademik. Jurnal Media Informatika Budidarma, 4(2), 347-354. https://doi.org/10.30865/mib.v4i2.2061 
IN F O R M A T I A

Jurnal Informatika, Manajemen dan Komputer, Vol. 12 No. 2, Desember 2020

eISSN : 2580-3042

pISSN : 1979-0694

Lee, J. S., \& Yoon, K. (2014). Mobile Digital Signage System based on Service Delivery Platform. In Conference: 2014 16th International Conference on Advanced Communication Technology (ICACT). https://doi.org/10.1109/ICACT.2014.67790 48

Mulyana, A., \& Aria, M. (2015). Perancangan Digital Signage sebagai Papan Informasi Digital. Majalah Ilmiah UNIKOM, 13(2), 111-118.

Panuntun, R., Rochim, A. F., \& Martono, K. T. (2015). Perancangan Papan Informasi Digital Berbasis Web pada Raspberry pi. Jurnal Teknologi Dan Sistem Komputer, 3(2), 192-197.

Suranata, I. W. A., \& Wardana, I. N. K. (2014). Digital Signage sebagai Media Penyampaian Informasi Kegiatan Akademik Berbasis Mikrokomputer. Creative Information Technology Journal, 1(4), 306-315. 